\title{
Mulher e reprodução: questão de Estado
}

\author{
Fabíola Rohden
}

\section{SciELO Books / SciELO Livros / SciELO Libros}

ROHDEN, F. Mulher e reprodução: questão de Estado. In.: A arte de enganar a natureza: contracepção, aborto e infanticídio no início do século XX [online]. Rio de Janeiro: Editora FIOCRUZ, 2003, pp. 179-218.

História e saúde collection. ISBN: 978-65-5708-117-4.

https://doi.org/10.7476/9786557081174.0008.

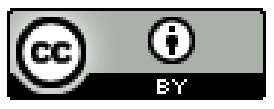

All the contents of this work, except where otherwise noted, is licensed under a Creative Commons Attribution 4.0 International license.

Todo o conteúdo deste trabalho, exceto quando houver ressalva, é publicado sob a licença Creative Commons Atribição 4.0.

Todo el contenido de esta obra, excepto donde se indique lo contrario, está bajo licencia de la licencia Creative Commons Reconocimento 4.0. 


\section{Mulher e Reprodução: questões de Estado}

Ao longo do tempo, nota-se uma certa redefinição no discurso médico que enfatiza cada vez mais o papel da mulher em virtude de sua importância para a nação. Isso reflete uma aproximação maior da medicina com o Estado. Mas também diz respeito a uma série de outros desenvolvimentos em curso, como uma forte presença das idéias eugênicas, a propagação dos métodos de controle da natalidade, o trabalho feminino fora de casa, a organização das mulheres reivindicando direitos ${ }^{1}$ e a importância adquirida pela questão da população e da raça.

A partir da década de 1930, alguns vetores do processo de construção de uma imagem feminina por meio da reprodução vão se acentuar e dar um tom bastante específico ao quadro que vem se desenhando desde o século XIX. Não tenho a intenção de detalhar o que aconteceu nessa década, repleta de grandes movimentos. ${ }^{2}$ Mas algumas articulações parecem tão significativas considerando-se o âmbito deste livro que não poderiam deixar de ser mencionadas. Acredito que, por um lado, representam, de certa forma, o ápice de um processo de conexão entre o pensamento médico sobre a mulher, a noção de uma medicina intervencionista e bastante próxima do Estado e a propagação mais acentuada das idéias eugênicas. Por outro, esse novo contexto significa o ponto de partida para uma outra história, que envolve cada vez mais novos e complexos processos em jogo. Nesse sentido, este capítulo funciona como um fechamento porque mostra a que lugar chegaram alguns dos processos ou idéias que vinham se conformando nos âmbitos da medicina e da justiça desde o século XIX, mas implica também uma grande abertura, que propõe algumas possibilidades de articulação com questões bem mais amplas e complexas. 


\section{A Inspiração Eugênica: casamento, sexo e fertilidade}

Durante as primeiras décadas do século $\mathrm{XX}$ pode-se perceber que os debates em torno da reprodução e do controle da natalidade ganhavam um tom particular a partir da ascensão das idéias eugênicas. ${ }^{3}$ Contudo, podemos detectar as origens desta linha de preocupações que relaciona eugenia e reprodução em uma série de trabalhos que tratam da chamada higiene do casamento, já desde a segunda metade do século XIX. O interesse pela reprodução e sexualidade do ponto de vista da 'higiene da raça' vinha pouco a pouco motivando uma maior atenção, sobretudo por parte dos médicos.

A preocupação com o casamento aparece com destaque nas teses da Faculdade de Medicina do Rio de Janeiro a partir da década de $1870 .{ }^{4}$ Desde essa época, os médicos demonstram um interesse grande pelo casamento, na medida em que esse tema se associa com sexo e procriação e a manutenção da ordem social (a família, a nação) e mesmo natural (a sobrevivência da espécie).

Vários trabalhos dessa fase têm o sugestivo título Dos casamentos do ponto de vista higiênico, como aquele de Frederico Augusto dos Santos Xavier (1876). Essa tese é um belo exemplo do modo como se enfocava o casamento sob diversos ângulos. A introdução do trabalho começa falando da importância da família. O primeiro capítulo trata "do casamento e seus caracteres". Nesse item, Xavier chama a atenção para o papel do médico, que deve fazer respeitar as leis naturais a despeito dos interesses ou conveniências em prol do futuro da humanidade. $O$ autor pronuncia-se definitivamente contra os casamentos arranjados, que muitas vezes constituem uniões que a higiene reprova, porque os filhos se ressentirão dos vícios paternos. As paixões, os prazeres e os vícios dos pais concorrem poderosamente para a vida dos filhos e podem influir na degradação da espécie. Os higienistas dão exemplos de descendentes que no decorrer da vida foram acometidos por moléstias mentais atribuídas ao estado de saúde dos pais no momento da cópula.

Diz Xavier (1876:12) sobre a relação entre o médico e o casamento:

É portanto dever do médico higienista, consultado em questão de casamento, afrontar as iras dos interessados, estudar a vida dos nubentes, seus costumes, inquiri-los sobre a realidade de suas afeições, e, como juiz íntegro e órgão sublime da sociedade, pronunciar seu voto para que essa união se realize ou se destrua; e mais tarde, quando, com calma e razão, aqueles que desprezavam os conselhos do higienista, 
tiverem reconhecido a verdade, abençoá-lo-ão por ter ele exercido duplamente a profissão de sacerdote da ciência e da sociedade, pois que só teve em vista evitar certas moléstias, prolongando-lhes a vida.

Xavier acrescenta que o casamento é uma barreira contra a imoralidade e a corrupção. Os homens que desconhecem as vantagens da monogamia procuram a satisfação dos seus desejos através da variedade e acabam por ter todos os sentidos pervertidos. E os seus organismos, com as perdas contínuas do "licor prolífico", vão se depauperando. O coito variado e constante produz ainda uma superexcitação cerebral, que dá origem a uma série de moléstias que acabam por inutilizar o homem no exercício de todas as suas funções. Já no casamento em que predomina a moral imposta pela higiene, o homem e a mulher se enobrecem e poupam os 'prazeres genésicos' em favor do embrião.

No segundo capítulo, o autor trata "das qualidades morais e físicas que devem ter aqueles que contraem o casamento" e "do celibato", incluindo as vantagens do casamento sobre o celibato. Afirma que a primeira condição a ser exigida para aqueles que desejam se unir é a perfectibilidade dos órgãos da geração. Como o fim mais importante do casamento é a reprodução, é em torno dessa qualidade que se devem focalizar as preocupações dos médicos que avaliam o sucesso de um casamento futuro. Quanto ao celibato, Xavier tenta mostrar como fora reprovado desde as mais antigas épocas e chega a citar lugares onde os celibatários tinham que pagar impostos especiais. Utiliza dados de Bertillon para dizer que a mortalidade é muito maior entre os celibatários. O maior número de suicídios, assim como de presos e de alienados, se refere a celibatários. Essa categoria de pessoas tem de enfrentar as agruras da vida isoladamente e sem o apoio dado pelo cônjuge e pela família. Os celibatários entregam-se sem medida às suas inclinações e acabam depauperando sua existência. Destroem uma vida que poderia ser útil à família e à pátria, que precisam sempre de protetores e cidadãos honestos e devotados. Nos casados, observavam-se a regularidade da vida e dos prazeres genésicos, o amor sincero e leal dos cônjuges, os cuidados que reciprocamente se prestam, sem falar da educação dos filhos, que mais tarde darão apoio aos progenitores.

Xavier também discute a idade mais conveniente para o casamento e os problemas das uniões precoces ou tardias. Segundo ele, o ideal seria entre 24 e 25 anos para os homens, e 19 e 20 anos para as mulheres. Esta preocupação com a idade também reflete o interesse na reprodução 
saudável. Os cônjuges muito moços, por exemplo, não têm condições ainda de produzir filhos com uma constituição vigorosa. Já os homens com mais de 45 anos têm sua faculdade reprodutiva reduzida. Os filhos de pais mais velhos, assim como de jovens que se desgastaram muito não terão como escapar dos problemas decorrentes de uma constituição fraca. O autor menciona ainda outras facetas dos casamentos não aprovados pela higiene, como o ridículo que pesa sobre as mulheres mais velhas que se casam com jovens rapazes (Cf. cap. 3 ).

O quarto capítulo considera a influência da herança no casamento e o casamento como meio curativo. Ressalta que o médico deve sempre alertar os progenitores sobre as doenças que possam transmitir à sua prole. Nesse item, Xavier introduz mais explicitamente as intenções, que mais tarde poderiam ser qualificadas de eugênicas, previstas nesse projeto de regulação do casamento pela medicina. Descreve como, através de determinados 'cruzamentos' previstos pelos higienistas, seria possível destruir as moléstias hereditárias. Dessa forma, os componentes de uma 'raça inferior' poderiam ser absorvidos pela 'raça superior' em prol da evolução da espécie. Essa perspectiva não se restringia ao plano da discussão meramente especulativa, mas adquiria um aspecto intervencionista claro. O autor reclama a criação de uma lei que proíba o casamento quando o estado de saúde dos cônjuges for mórbido, diagnóstico que, evidentemente, é tarefa dos médicos.

Xavier trata ainda dos casamentos consanguíneos, que, ao contrário de muitos contemporâneos seus, não vê como perigosos para a boa descendência (Cf. cap. 5). E fala das contra-indicações dos casamentos, como as moléstias e vícios de conformação, a alienação mental, a epilepsia, a tuberculose pulmonar, a sífilis, as afecções do coração, o raquitismo etc. (cap. 6). No capítulo sete, o assunto central são as relações conjugais, o que significa, nesse contexto, a prática do ato sexual. O autor chama a atenção para os efeitos perniciosos do ato sexual durante a menstruação, a prenhez e o aleitamento. Condena o "terrível vício do onanismo conjugal" que arrasta o homem e a mulher a superexcitações nervosas de tal ordem que em pouco tempo passam a apresentar as mais profundas desordens orgânicas. A responsabilidade por essa situação deve ser lançada sobre o homem, que induz a mulher, ainda jovem, a esses atos que ferem o pudor e aproximam os homens dos animais irracionais. Xavier adverte que os homens devem respeitar o leito da esposa, compreendendo que na aliança conjugal não deve haver lugar para o amor sensual, mas sim para 
um certo grau de castidade. A transposição da vida libertina que o homem tem na rua para o interior do casamento é o início da perversão do seu fim principal, a procriação:

A vida anterior do esposo, a depravação de seus costumes é algumas vezes de tal ordem, que a esposa ouve o histórico dessas cenas escandalosas que seu marido quando solteiro praticou. Não satisfeito em relatar a sua esposa os episódios de sua vida libertina, torna o lugar santo do leito nupcial o teatro de sua lascívia, não respeitando em suas relações conjugais a natureza do instinto orgânico. Ensinando à mulher o que ela deveria sempre ignorar, não reflete nas conseqüências terríveis do mal que pratica, e rompe o fim principal do casamento, que consiste na procriação, não só ofendendo a moral, mas também produzindo no organismo graves desordens. (Xavier, 1876:66-67)

O último capítulo da tese é dedicado aos conselhos médicos. É a hora de Xavier reafirmar a importância do médico higienista. O autor explica como esse profissional está voltado para os interesses não só privados, dos indivíduos e das famílias, mas também públicos, da sociedade. É um agente que tem a responsabilidade de possuir todos os segredos das famílias e deve saber lidar com isso. Esses segredos só devem ser utilizados em busca do aprimoramento das uniões que construirão uma descendência saudável. Xavier termina lamentando que, infelizmente, para as próprias famílias, ainda se dava muito pouco apreço à higiene.

Também José Teixeira de Coelho (1878), em sua tese, se preocupa em advertir que os médicos devem ser chamados a cuidar do casamento, de modo que essa união possa servir às aspirações e ao progresso da sociedade e não à sua decadência e ruína. O casamento é a união de pessoas que visam se complementar mutuamente, criar uma nova familia, educar os filhos. É um meio de aperfeiçoar a humanidade não só a partir da procriação:

O fim do casamento não é, como muitos pensam, único e determinado, a procriação, ou a união entre dois seres que mutuamente necessitam um do outro; não é, porque, tornando indissolúvel a união do homem e da sua companheira, constitui ao mesmo tempo uma sociedade espiritual e material, por meio da qual a humanidade se aperfeiçoa, se ampara e se auxilia. (Coelho, 1878:9)

A congregação do homem em sociedade é uma necessidade absoluta, imposta pelas exigências da sua própria conservação e pelas necessidades do seu físico e do seu moral. O casamento contraria a mortalidade da 
espécie e a desagregacão social. Além disso, a cópula, por si mesma, é uma outra necessidade imperiosa:

É da máxima utilidade o casamento ainda, porque é de imperiosa necessidade para o organismo a aproximação dos sexos, a cópula, como uma necessidade da natureza. E quem nos contestará que essa prodigiosa força prolífica retida no organismo não concorre para um aniquilamento mais precoce, proveniente de uma atrofia dos centros nervosos causada pelo acúmulo do gérmen seminal? (p. 12)

Coelho prossegue o trabalho definindo os aspectos que devem orientar a função do médico na 'confecção' do casal higiênico. Discute o problema da consangüinidade e conclui que é verdade que os casamentos consangüíneos podem enfraquecer a descendência. Mas isso só acontece com aqueles pais já degenerados e fracos. Ao contrário, se o casal for 'selecionado' pelos médicos, o resultado será o aperfeiçoamento dos mais fortes. Através de uma seleção minuciosa, o homem obtém facilmente a modificação das características de animais e vegetais. Isso pode ser percebido tanto na jardinagem quanto na criação de pombos e coelhos, sendo extensível ao homem. O autor cita Darwin e Spencer, e recorre à seleção natural para justificar também a operação de uma seleção artificial. Exemplifica seu projeto com os espartanos que matavam as crianças com vícios de conformação ou nutrição, o que, segundo ele, fez com que a 'raça espartana' se mantivesse em um estado excepcional de força e vigor. Critica os médicos que têm atuado na seleção dos melhores homens para serem enviados à guerra, enquanto deixam que os fracos sobrevivam e se multipliquem, transmitindo seus vícios hereditários. Coelho destaca o papel importante da herança na proliferação de entes degenerados, tanto no que diz respeito a caracteres físicos quanto morais. $O$ autor condena ainda os casamentos feitos com base no interesse, no egoísmo e na solidariedade de família que, para sofrimento de todos, têm como regra a consulta antes ao tabelião $\mathbf{e}$ ao banqueiro do que ao médico.

A partir dos resumos dessas duas teses, ainda da década de 1870, é possível diagnosticar uma tentativa por parte da medicina de redefinição dos valores atribuídos aos papéis desempenhados por homens e mulheres. Tem destaque em particular a importância atribuída à mulher como base da harmonia e da moral do lar. Paralelamente, a sua função de reprodutora ganha novos contornos em virtude de uma preocupação médica mais acentuada com a questão do aperfeiçoamento da raça e progresso da nação. 
Através da medicina, a mulher parece ser convertida em um instrumento determinante da evolução da espécie e do futuro da pátria. Ela adquire quase que um novo status mas continua tendo o destino definido a partir da vida privada e da reprodução.

Um pouco mais tarde, já no século XX, a discussão sobre o papel da mulher, o casamento, a família, a sociedade e a raça se aprimorava. No trabalho de Aristides Campos Seabra, de 1902, que estuda o tema sob o ponto de vista da medicina legal, temos mais uma vez uma proposta clara de aproximação entre medicina e justiça. Para o autor, seria pela associação entre esses dois campos que se poderia chegar a uma otimização das funções do casamento na sociedade.

Seabra afirma que o casamento deve ser considerado a partir de dois princípios. O primeiro é o sociológico e baseia-se na constituição da família. O segundo é o científico, e fundamenta-se na evolução da raça humana. Seabra (1902:6) explica esse ponto:

O casamento em si, sem preocupação da forma, da pragmática social, do código civil ou dogma religioso, tem por base fundamental e orgânica a constituição da família. A família assim constituída, congregada e sujeita à reciprocidade ética, é o princípio fundamental e indiscutível da sociedade. Perante a ciência o casamento é perfeitamente definido na evolução da raça humana; perante a sociedade é o casamento definido no princípio da Ética moderna. Firmando-se no princípio irrevogável do naturalismo, o instinto de conservação do individualismo humano o conduz a procriar um indivíduo semelhante, como meio único e fatal de garantir a perpetuação da espécie humana através dos séculos. (Grifos do autor)

O médico deveria ser chamado a contribuir no âmbito da organização da família. A jurisprudência deveria recorrer ao médico para a formulação da lei do casamento, o que não acontecia no Brasil, onde princípios errados orientavam a legislação. Já no plano da evolução da raça, é ainda mais patente a necessidade de privilegiar o saber científico, único meio capaz de impedir a reprodução dos indivíduos considerados perniciosos à espécie:

A Medicina devia, em todos os tempos que tem recebido os influxos benéficos dos tentames civilizadores, ocupar um plano mais elevado, de maneira a tolher sempre e em primeiro lugar, o direito de ingresso no templo de Hymeneo aos indivíduos, nos quais ela reconhecesse incapa- 
cidade vital, e, com severidade devia embargar o concurso deles, na obra majestosa da evolução da raça humana. Ela devia tolher o direito desses indivíduos concorrerem para a estirpe semelhante, rica em espécimes teratológicos e mórbidos. Já é tempo da Medicina pôr termo ao direito abusivo de um monstro reproduzir um outro monstro, de um demente reproduzir um outro demente, de um sifilítico reproduzir um outro sifilítico, de um alcoólico reproduzir um outro alcoólico, etc. Enfim, deve impedir o abusivo direito de um indivíduo mórbido engendrar um outro indivíduo doentio. (Seabra, 1902:8)

O autor trata da hereditariedade patológica para depois passar ao estudo médico legal propriamente dito. Começa com os motivos de impedimento do casamento e sustenta a defesa do exame médico antes do casamento, com o fim de identificar os males que justificariam o impedimento da união. Têm destaque as nevropatias, como a loucura, a epilepsia, o histerismo e a neurastenia. Em seguida, considera os motivos de nulidade do casamento. Utiliza o exemplo do código civil francês, que prevê os erros quanto à pessoa. Entre estes, está o hermafroditismo, que justifica a anulação. $O$ autor salienta que se os noivos passassem pelo exame médico, esse tipo de problema não aconteceria. Outro motivo de nulidade é o desvirginamento da mulher. Dessa vez Seabra critica as leis brasileiras por não definirem precisamente o critério do desvirginamento, isto é, qual a sua causa: se a cópula carnal, a masturbação ou o traumatismo. O último capítulo é dedicado ao divórcio. O autor defende o direito ao divórcio argumentando que o fim de uma união desastrosa possibilita aos indivíduos chances de buscar novos parceiros, e com um novo casamento poderão contribuir para o progresso da sociedade. ${ }^{5}$ Em todos os itens tratados, a defesa do conhecimento médico como fonte imprescindível para a reelaboração de uma legislação adequada e para a realização prática dos preceitos defendidos é insistente.

Como foi possível perceber, nos trabalhos médicos sobre casamento, entrava em cena uma acentuada preocupação com a reprodução dos indivíduos, a manutenção da família e da sociedade. Também com base na leitura de teses e outros documentos do período, podemos identificar uma crescente ênfase na necessidade de proteção à infância e à maternidade. No conjunto de teses defendidas na Faculdade de Medicina do Rio de Janeiro, nota-se um elevado número que trata da maternidade e da infância a partir da virada do século. Temas mais antigos, como o aleitamento, juntam-se a novos conceitos que refletem os interesses em voga, como a 
proteção à maternidade e a puericultura. ${ }^{6}$ Trabalhos como o de Ugolino Penteado (1905), Do Valor da Puerimetria, exemplificam o acentuado nível de especialização dos estudos que começava a se instaurar naquela época no que se refere à preocupação com a criança. O autor adverte o leitor sobre como o tema tratado é novo e define a puerimetria como a parte da puericultura que trata do desenvolvimento físico da criança. Uma das principais características é o estabelecimento das diferenças de peso e estatura nas crianças consideradas normais ou anormais. A esse gênero de trabalhos se acrescentaria um outro, bastante particular, que se refere à relação entre o trabalho feminino e a maternidade. E mais uma vez o tema da reprodução era discutido à luz do futuro da nação e mesmo da espécie.

\section{Prejuízos do Trabalho Feminino e Necessidade de Proteção}

No que se refere ao problema da proteção à maternidade, uma tema de bastante destaque passará a ser as dificuldades impostas pelo regime de trabalho industrial. O estudo de João Passos (1913) trata especificamente Da Escravidão da Mulher pelo Industrialismo e do Conseqüente Malefício para a Espécie. O trabalho começa fazendo referências a Comte e à regeneração da espécie com o regime positivo. Para o autor, é através da hereditariedade que os aperfeiçoamentos operados nas espécies vão se fixando nas gerações. Os melhoramentos que primitivamente eram de ordem artificial vão se tornando naturais com o passar do tempo. O 'tipo feminino' tem importância fundamental nesse processo na medida em que acumula a função da reprodução e da transmissão, agindo através da hereditariedade e da educação sobre a organização humana. A mulher está predestinada a agir no tempo e no espaço de modo a desenvolver os atributos físicos, intelectuais e morais da espécie. O 'tipo masculino' também realiza incessantes aperfeiçoamentos, mas que se referem à solidariedade e à comunidade humanas. Seus predicados se relacionam particularmente com o exercício da atividade exterior, industrial, que atua no sentido de converter o planeta em um paraíso para a espécie. Ou seja, a mulher reproduz e educa, funções da esfera privada, enquanto o homem produz e transforma o mundo exterior (Passos, 1913:14-26).

Com a evolução, esta especialização de funções foi se configurando mais claramente e tornou-se visível até mesmo nas características anatômicas e fisiológicas de cada um dos sexos. O autor explica: 
Prosseguindo em sua evolução incessante, o homem teve de triunfar de todos os obstáculos que se opunham ao seu desenvolvimento normal, requintando todas as faculdades de ação sobre a natureza cosmológica.

A Mulher, outrossim, na grande complexidade de sua organização, começou à medida que o nosso desenvolvimento coletivo se foi efetuando, a experimentar novas contingências inerentes ao fim a que era destinada.

Mais acessível às influências modificadoras, sem o que não poderia corresponder ao seu destino, o seu organismo ostentou-se de mais em mais apto aos seus dignos misteres.

O fenômeno periódico da menstruação, esboçado em algumas espécies mais próximas da nossa, e apenas presente no estado selvagem, adquiriu com a evolução social uma enorme preponderância que pode denunciar os efeitos da estreita solidariedade cerebral no conjunto da vida vegetativa. (...)

A sua condição de periodicidade desfalca o ritmo fisiológico e requer uma higiene muito mais severa e incompatível, pelo menos durante esse período fluxonário, com a atividade forçada, exterior, industrial, do abnegado sexo.

O advento da concepção multiplica enormemente o número de condições capazes de promover pela sua evolução a ruptura do equilíbrio normal. (Passos, 1913:27-28)

O autor ainda acrescenta que o trabalho industrial da mulher é inadmissível social e moralmente devido ao fato de que não se pode conjugar com sua função primeira que é a reprodução. O período menstrual, a gestação e a lactação deixam evidente que o organismo feminino está sempre sujeito à "máxima atividade fisiológica". E sobrecarregá-lo com esforços físicos obrigatórios "é positivamente um grande crime". Passos, para corroborar seu raciocínio, cita algumas estatísticas que demonstram como o trabalho representa um grande perigo para a gestação. Percebe que o problema central é a ameaça que o trabalho fora de casa representaria para o número de nascimentos e saúde das crianças e não, por exemplo, a preocupação com o desgaste físico e a saúde da mulher em si mesma. É neste sentido que o autor afirma:

Se quisermos conseguir uma humanidade forte e perfeita, física e moralmente, temos de cercar a Mulher, a quem está afecto esse grandioso acontecimento [a gestação], não por vontade nossa nem de ninguém, 
mas pelas leis imutáveis da fatalidade, de todas as condições capazes de garantir o melhor êxito de uma empresa em que ela acumulou todos os seus poderes.

De modo que não precisamos sair do simples domínio biológico para verificarmos o quanto é monstruosa a moderna organização social, em que a Mulher vai sendo cada vez mais sacrificada à criminosa cobiça do regime industrialista. (p. 30-31)

Verifica-se que Passos acentua o caráter da fatalidade da gestação, que teria como conseqüência imprescindível o seu afastamento do mundo do trabalho. Afirma também que as naturezas masculina e feminina são absolutamente heterogêneas e complementares e assim devem permanecer. Foi por isso que a humanidade inventou a família, o modo pelo qual homens e mulheres interagem e se complementam. $O$ industrialismo moderno, escravizando a mulher, age precisamente nesse equilibrio harmônico, fomentando a dissolução da família, o aniquilamento geral da sociedade, e a falência da dignidade do homem mal remunerado que assiste sua mulher abandonar o lar. ${ }^{7}$ Nas conclusões da tese, Passos sugere que, para famílias com dificuldades de subsistência, a solução a ser procurada deve consistir em um subsídio do governo. Evita-se, assim, o trabalho da mulher que, em última instância, colocaria em risco a própria espécie. É, portanto, em nome da sobrevivência da espécie que a mulher deve ser impedida de trabalhar. É avaliando o futuro da espécie que a medicina mais uma vez converte a mulher em uma categoria a ser estudada e tutelada.

A tese de Carolino Ribeiro Moura (1917) enfoca a assistência à maternidade desvalida, um conceito que se refere às dificuldades decorrentes do trabalho feminino fora de casa. O tema central é de novo a incompatibilidade da fábrica com a gestação. Mas, o autor avança no sentido de propor e exigir do governo medidas que obriguem as fábricas a permitir o repouso das grávidas. Também é sugerida a criação de um sistema de atendimento à gestante e aos recém-nascidos, como o acesso a consultas médicas, a abertura de asilos e maternidades para as operárias, a reforma da legislação, a elaboração de um plano de assistência à maternidade no Rio de Janeiro e a obrigatoriedade da consulta de lactentes, além da criação de um serviço de aleitamento e de creches. $O$ autor parece não pretender o fim do trabalho industrial feminino, mas sim a sua regulamentação a partir dos pressupostos médicos. Contudo, as razões do seu projeto continuam mais referenciadas ao aperfeiçoamento da raça e da nação do que ao 
bem-estar das mulheres e das crianças. Isso fica evidente quando diz que, com a falta de regulamentação do trabalho das mulheres grávidas, está em jogo o fato de que "uma raça, uma nação, podem se ver mais ou menos rapidamente ameaçadas de enfraquecimento; a uma geração doentia sucederá uma geração ainda mais empobrecida em suas forças vitais" (Moura, 1917:11).

Alceu Marques Ladeira (1919) também se preocupa com a maternidade nesse sentido. Começa seu estudo com a descrição das influências negativas do trabalho feminino sobre as gestantes e sugere a proteção legal de menores e mulheres no que se refere ao trabalho. Essas duas categorias deveriam ser vigiadas e tratadas, para o bem da nação. $O$ autor considera também a ação prejudicial das habitações coletivas sobre as gravidezes. Defende a importância da chamada puericultura intra-uterina e propõe a criação de ambulatórios, maternidades e creches.

A preocupação dos médicos incidia também sobre algumas categorias particulares de trabalhadoras, como, por exemplo, as professoras. A tese de Faustino de Castro (1919) defende a proteção legal à professora grávida. O trabalho se divide na consideração da puericultura anteconcepcional ou intra-uterina, nas conseqüências do trabalho sobre a gestação e o período pós-parto, além de uma proposta sobre a legalização do repouso das professoras grávidas. O aspecto mais interessante desta tese está na discussão inicial, em que Castro fala das reivindicações feministas. O autor condena as feministas que alargam o escopo de suas exigências sem incluir a proteção à gravidez. A referência à nação não é deixada de lado. Castro adverte que a maior riqueza de uma nação é o homem. E é o fato dele nascer através da mulher que faz com que ela, especialmente no período da gravidez, mereça a atenção dos legisladores.

Não era apenas nas teses apresentadas à Faculdade de Medicina que o tema da assistência à maternidade aparecia. Estava presente também em congressos, livros e periódicos, pelo menos até a década de 1940. No Brazil Medico encontramos várias referências sobre o assunto, como o artigo de Assad M. Abdenur (1941), que teoriza a respeito do alcance da 'ginecologia social' e do desenvolvimento da 'praxipatologia feminina'. Essa última é definida como a disciplina que estudaria as causas, os meios e os modos pelos quais o trabalho prejudicaria a biologia da mulher. Teria como foco, apoiada nos pontos de vista social, político, médico e legal, os acidentes e as causas mórbidas associados ao trabalho feminino. Seriam tratadas especialmente aquelas que direta ou indiretamente são responsá- 
veis pela infecundidade, esterilidade, desvios do instinto sexual, interrupção da gravidez, anormalidade do parto e das funções genitais. O autor afirma que a ampliação das atividades industriais e burocráticas atribuídas em maior escala às mulheres, principalmente após a Primeira Guerra, vinha aumentando o número de vítimas desses distúrbios. Segundo Abdenur (1941:522):

A convivência em ambientes masculinos, o desempenho de tarefas árduas, afastam e desviam o instinto sexual, o materno, atentando contra a diferenciação sexual do trabalho e às finalidades naturais do sexo. Que esse desvio é anormal e existe não há dúvida. É conhecida a tendência desigual em ambos os sexos, desde a infância, por diversões e brinquedos. A preferência da menina por bonecas, às quais presta os mesmos carinhos que recebe, já revelam o despertar do instinto materno. A idade não apaga, antes desenvolve e adapta essas qualidades inerentes ao sexo. As tarefas másculas agem desviando esse instinto, logo têm ação mórbida, seja por mecanismo psíquico, seja por mecanismo orgânico.

$\mathrm{O}$ artigo termina dizendo que "A ginecologia social tem em nossa Pátria missão elevada a cumprir. Oxalá os seus progressos sejam bem compreendidos e aproveitados no sentido de melhora eugênica e valorização de nosso povo" (p. 522). ${ }^{8}$

O trabalho da dra. Antonietta Morpurgo (1911), uma das poucas mulheres que vemos aparecer nessa história, elaborado ainda na década de 1910, caminha na mesma direção. Essa médica tinha apresentado no IV Congresso Médico Latino-Americano uma comunicação sobre a assistência às mulheres grávidas, que repetiu em uma reunião da Sociedade de Medicina e Cirurgia, e que o Brazil Medico transcreveu. No texto, a autora começa lamentando o alcance do aborto criminoso em nosso país. A prática do aborto estaria na raiz do problema da deficiência da natalidade. Afirma que é praticado por três tipos de mulheres: aquelas menores de idade que o fazem para evitar a reprovação moral de uma gravidez ilícita; as proletárias motivadas pela miséria e a falta de meios; e as mulheres ricas, que vivem na fartura, com todo o conforto e higiene, mas que praticam o crime devido à sua falsa moral. A médica defende que especialmente o proletariado seja protegido não só materialmente, das intempéries e da fome, mas também espiritualmente, através da educação de acordo com os preceitos da higiene e da assepsia. Dessa forma, o número de abortos diminuiria e a taxa de natalidade cresceria. 
Antonietta Morpurgo sugere a criação de um serviço de assistência obstétrica domiciliar que teria a vantagem da proximidade com a familia. Dessa maneira "o que era doloroso momentos antes, pouco depois tornase a alegria pela compensação bem grande em possuir mais um filho para a Pátria, para o lar" (p. 145). A autora continua dizendo que "Todo o país que zela a conservação da sua raça, promove a assistência à mulher grávida pobre na sua própria residência" (p.145). Os argumentos a favor da assistência giram em torno de mais um filho para a Pátria e da conservação da raça. Entre as conclusões de seu trabalho estão incluídas:

Fazer assistência obstétrica domiciliária é fazer puericultura, é concorrer para essa obra sublime, assunto momentoso e importantíssimo no mundo civilizado. É um meio heróico a opor à mortandade infantil, já exagerada entre nós, e de aumentar a natalidade. (...)

Urge que o governo de nossa pátria se lembre de proteger as mães necessitadas nos próprios lares, levando-lhes o socorro a que têm direito pela sublime função da maternidade desamparada. (...)

A assistência à mulher grávida no seu próprio lar impõe-se como complemento da felicidade e representa o mais alto serviço que a nossa classe pode prestar à pátria e à humanidade. (Morpurgo, 1911:145)

Destaca-se no trecho citado, além de uma apreensão evidente com a questão da natalidade, a cobrança de uma atitude do governo em prol da assistência à maternidade. A medicina realiza a tarefa de identificar o problema e apontar as soluções que devem ser tomadas pelos poderes públicos. Nota-se também a referência ao papel primordial da medicina como protetora da mulher grávida.

A autora ainda faz referência ao seu trabalho no Instituto de Assistência e Proteção à Infância, onde, segundo ela, muitas mulheres têm sido auxiliadas material e moralmente e muitos abortos têm sido evitados. Fala também da necessidade de educar as jovens por meio de conferências nas escolas públicas, a fim de que elas aprendam a ciência da puericultura, os preceitos da antissepsia, os cuidados com o recém-nascido, noções sobre alimentação e aleitamento. A arte de ser mãe inclui o conhecimento de orientações religiosas, além da higiene da puericultura (p. 145). É possível perceber que não é mais o instinto materno que reina soberano, mas a idéia de que as mulheres devem aprender como realizar a sua missão com base nos ensinamentos propostos pela medicina. 


\section{A Educação das "Sacerdotisas da Eugenia"}

Antonietta Morpurgo dá bastante destaque à questão da educação da mulher para a maternidade. Na verdade, o tema da educação feminina adquiria cada vez mais importância nos debates médicos. As preocupações da médica focalizavam especificamente a preparação da mulher para a realização satisfatória da função que se imaginava ser o seu destino. Porém, para outros autores, a discussão em torno da educação feminina era bem mais complexa, envolvendo de maneira mais profunda a relação entre a mulher e a raça ou a espécie.

Para entendermos o arcabouço de concepções predominantes no pensamento médico do começo do século XX é fundamental fazer referência a uma obra da última década do século XIX. Trata-se do livro de Tito Livio de Castro, intitulado $A$ Mulher e a Sociogenia, ${ }^{9}$ que foi escrito em 1887 e publicado em $1893 .{ }^{10}$ No prefácio, o autor explica que seu objetivo é determinar qual a posição social da mulher e o que ela representa como fator sociogênico. Já no primeiro capítuló passa ao estudo do crânio e do cérebro femininos para poder explicar a sua função. Afirma que as pesquisas demonstravam que o cérebro feminino pelo peso, volume e forma é inferior ao masculino. Já as células da medula na mulher são maiores do que no homem.

A questão proposta é então determinar quando e em razão de que resulta essa inferioridade. Castro afirma que a superioridade cerebral masculina já se manifesta no recém-nascido e é uma aquisição que se tornou hereditária. O tipo masculino teria passado por modificações e adaptações mais acentuadas que provocaram uma evolução mais significativa. Mas o cérebro de ambos evolui continuamente. O problema é que a evolução do cérebro masculino é muito mais rápida, e com o passar do tempo os prejuízos dessa separação entre os dois sexos serão muito acentuados. Como prova disso, Castro cita os estudos que afirmam que a inferioridade cerebral da mulher é tanto maior quanto mais adiantada é a raça à qual ela pertence.

$\mathrm{O}$ autor explica que a mulher foi a primeira propriedade, o primeiro animal doméstico a serviço do homem. Utiliza uma série de exemplos tirados da literatura antropológica da época para corroborar a idéia. Porém a mais importante constatação feita diz respeito ao fato de que a mulher sempre viveu de maneira relativamente calma e uniforme. A mulher não atravessou, como o homem, a vida acidentada que produziu a superioridade metafísica, a conquista e a domesticação de certos animais, uma 
musculatura mais desenvolvida, a astúcia e a hiperexcitabilidade dos sentidos. Resumindo, ela "não tomou parte ativa na luta pela existência, quer essa luta fosse travada entre forças musculares, quer entre recursos de astúcia" (Castro, 1893:81). A mulher pouco precisou do cérebro e por isso não se desenvolveu cerebralmente. O resultado é que esse órgão acabou sendo atrofiado por inação. Nesse panorama, homem e mulher não são companheiros, mas dois sexos que se exploram e garantem à mulher uma vida sem luta e também sem progressos. A diferença aumentou gradativamente e a mulher se converteu em um ente passivo, indolente $e$ parasitário. $\mathrm{O}$ autor afirma que isso é suficiente para explicar a dominação masculina. A boa notícia, de acordo com Castro, é que não estamos diante de um fenômeno inalterável. Se a causa do problema puder ser modificada, os efeitos serão suprimidos, apesar de alguns fisiologistas e antropologistas afirmarem que é utopia a esperança de um desenvolvimento mental na mulher.

Castro também chama a atenção para a proximidade da mulher com a criança e com o selvagem. Observações colhidas com o método etnográfico e com a craniometria têm confirmado esta relação. Segundo o autor, o homem primitivo, a criança de hoje e a mulher, feitas certas restrições relativas ao meio, representam a infância da humanidade. E assim como uma sociedade pode evoluir, a mulher também pode. Castro é partidário da opinião de que os hábitos adquiridos se tornam parte integrante e inseparável do organismo. O que aconteceu com a mulher foi que o meio em que viveu sempre se aproximou ao da infância ou da espécie no período primitivo. Ela não teve incentivos para chegar à maioridade, permanecendo até então como uma criança e dependendo sempre do homem. Dessa forma, a mulher pouco vinha contribuindo para a evolução da espécie.

$O$ autor acrescenta que a moralidade também acompanha a intelectualidade. E considerando que a mulher, além de reproduzir, em grande parte é responsável pela transmissão dos valores morais aos futuros adultos, seu papel deve ser avaliado com cuidado. Depois de uma longa análise, Castro chega à conclusão de que o único meio de intervir em prol do futuro da espécie é a educação. O que em um momento é a educação, em outro será a hereditariedade. A educação é tão importante que não pode ser deixada exclusivamente a cargo da mulher. E para que se pudesse pensar no futuro do Brasil era necessário avaliar a situação da sua população com relação à educação, uma tarefa da demografia. ${ }^{11} \mathrm{O}$ autor afirma 
que era patente o reduzido nível de educação entre as mulheres e, ponderadas as diferenças, também entre os homens. O Brasil constituía então um meio absolutamente impróprio para a evolução intelectual da mulher. Em nenhuma parte ela é educada de acordo com o papel que deveria representar na sociedade. Era preciso que o quadro fosse revertido.

A educação feminina é possível e mesmo bastante fácil. O autor tenta provar que não há nenhuma objeção científica à educabilidade da mulher. Ela é um organismo como os outros e sob a ação dos motivos que influenciaram os outros reagirá do mesmo modo que eles. O motivo nesse caso é a educação e a reação, a evolução mental feminina. Submetida a condições sociais mais análogas às do homem, a mentalidade da mulher necessariamente se aproximaria da mentalidade do homem. Com a estrutura, volume, peso e forma que possuía, o cérebro feminino poderia produzir mais do que o fazia até o momento. Castro fala das mulheres consideradas cultas e inteligentes como exceções que confirmariam a possibilidade de que a mulher poderia ser educada.

O autor afirma que o homem é também responsável por essa situação da mulher, na medida em que a defende contra a educação e a evolução mental. Ele age assim porque imagina que manter a mulher no estado atual de desenvolvimento é mais conveniente. Mas, na verdade, o homem e a mulher, da forma como estão, representam duas raças separadas e isso é prejudicial para o conjunto da espécie. Um dos argumentos evocados contra a educação feminina seria que ela contribuiria para o afastamento da mulher do lar e para a conseqüente dissolução da família. Castro responde que se a família, que implica um contrato, é baseada na ignorância da mulher e não em um acordo comum entre as duas partes, não pode ser benéfica para a evolução. Seria uma instituição retrógrada que precisaria ser modificada. Mas o fato é que a educação não dissolve a família porque esta não se baseia na ignorância da mulher. E cada vez mais deve ser fundada sobre a evolução paralela dos dois sexos. Nesse sentido, o casamento é entendido como "um contrato bilateral que procura o interesse biológico de dois sexos que se completam para a propagação da espécie" e a família é "o agrupamento de indivíduos solidários pela simpatia própria aos seres da mesma origem" (Castro, 1893:323).

Quando esse contrato for fielmente executado, contando com a evolução na mentalidade dos contratantes, a responsabilidade procriadora e genética estará em primeiro lugar. No momento, faltam ainda a liberdade 
dos contratantes e o conhecimento dessa sua verdadeira missão. Para Castro, é inexato que o lugar da mulher seja exclusivamente na familia e o do homem, na sociedade, já que família e sociedade só podem existir a partir da relação entre os dois sexos. Mas cada um deve desempenhar suas funções específicas, "porque a sexualidade é biologicamente uma divisão do trabalho" (p. 337). A função primordial da mulher é a procriação. Porém, ao contrário daqueles que defendiam que a mulher deveria ficar restrita ao lar para dar novos rebentos ao mundo, Castro sustenta que era necessário que a mulher procriasse indivíduos dignos da espécie. E para tanto ela precisaria ser educada e evoluir mentalmente. Em última instância, a educação da mulher deveria ser feita porque ela era necessária ao homem. Além disso, com o advento do industrialismo, se a mulher pobre não fosse educada sofreria com a pobreza e acabaria se tornando prostituta. E as ricas poderiam cada vez mais ser afetadas por problemas de ordem mental (p. 357).

Resumindo as conclusões do autor, a educação da mulher serve à seleção da espécie. ${ }^{12}$ Pela educação, que implicaria a aproximação da mentalidade feminina em relação à masculina, a evolução se tornaria mais fácil e mais rápida. Para Castro (1893:405), "O papel da mulher na sociogenia tem a significação de um dilema: ou a mulher há de evoluir, ou a espécie humana há de parar em sua evolução". ${ }^{13}$

A tese de Luiz Sparano (1916), que tem o sugestivo título de O Sexo em Patologia (a questão feminina), defendida vários anos mais tarde, apresenta pontos em comum com o trabalho de Tito Livio de Castro. Sua singularidade está na maior importância dada à eugenia e sua relação com o tema da nação. Sparano (p. 13) começa diagnosticando o problema da "influência do sexo feminino na evolução mórbida". Essa questão, que pertence à área da patologia social, é explicada a partir da civilização moderna. As contingências da vida civilizada, errroneamente orientada, é que teriam, ao longo do tempo, determinado a inferioridade física da mulher, prejudicial à espécie. A educação teve um papel central nesse processo.

$O$ autor sustenta que a educação da mulher em seu tempo era ruim e falsa. No fundo, não havia uma educação verdadeira nem do espírito e nem do corpo. A mulher apenas aprendia frivolidades, como escolher o vestuário anti-higiênico que deveria usar nos bailes. Os resultados desse descuido chegavam a prejudicar o desenvolvimento da nação. A falsa educação da mulher, que o médico tinha o dever de questionar, implicava a produção de indivíduos de má qualidade: 
Conhecedor dos funestos resultados de uma educação da qual se exclui toda noção de fisiologia, assistindo aos fatos da vida diária e sendo comparsa de uma civilização que tiraniza a organização sociológica da mulher tornando sua vida um fator tão importante no atraso do desenvolvimento nacional, favorecendo com seus males uma progênie de debilitados, e incapazes - de o médico erguer sua voz em favor da reforma radical do preparo elementar da educação física e intelectual da mulher. (Sparano, 1916:19)

É a educação também a responsável pela inferioridade feminina:

Salvando raras exceções, em todos os países a educação da mulher sofre o mal de origem e daí surge a inferioridade em que ela se encontra em relação ao homem. Seu físico relativamente inferior se apresenta com todos os males que essa inferioridade acarreta: - inconstância no pensar, volubilidade de idéias, caráter indeciso, hipernervosismo, perplexidade e medo e outros tantos e inúmeros defeitos que juntos ao egoísmo do homem, colocam-na irremediavelmente em plano inferior. (p. 20)

Sparano reconhece que as aberrações educativas têm relação com o progresso da civilização e o esquecimento dos ensinamentos da natureza. A própria natureza indica que a mulher deve ter seu 'lugar ao sol' e em raros campos pode ser considerada inferior ao homem. Ela entregou à mulher o papel fundamental da maternidade. O autor então se pergunta: "Como descuidar a educação física e a espiritual daquele indivíduo que, na propagação da espécie, é exatamente o que conserva em seu ventre o fruto humano e, nesse tão longo contato, dá-lhe a compleição física e transmite nas leis eternas da hereditariedade as qualidades do espírito?" (p. 22-23). Mas, o fato é que as escolas só vinham servindo para o estropiamento da mulher, ensinando que robustez, saúde e força seriam qualidades plebéias, ao passo que o apetite mal satisfeito, a timidez, o acanhamento e a fraqueza seriam apropriados às mulheres da alta sociedade. Dessa forma, sufocam as faculdades intelectuais e os movimentos físicos, o que tem como efeito a criação de moças doentes que, pela hereditariedade, propagarão as raças fracas:

A mocidade feminina moderna 'a flor mimosa e mais viva da natureza' é como uma dessas criações de plantas exóticas, reduzidas aos cuidados artificiais das estufas. Em vez de apresentar rosto animado, olhar cintilante, vivacidade e encanto, carrega a palidez das cloróticas, a languidez do olhar da timidez, as formas angulares dos músculos inexercidos, o relaxamento tendinoso, com as naturais tendências aos 
prolapsos, a anormal congestão dos órgãos genitais, as dificuldades de menstruação com todo o seu séquito da insuficiência de funcionamento das glândulas endócrinas.

Não é um ser vivo o que a educação prepara: - é uma hipocondria ambulante, transmitindo por hereditariedade esta terrível sentimentalidade lacrimosa das raças fracas, em que tudo se resolve ou nos exageros declamatórios, em que mais agem os nervos que os músculos, ou na fragorosa catadupa das lágrimas... (Sparano, 1916:24-25)

O autor ainda chama a atenção para o fato de que os poderes públicos nada vinham fazendo para reverter tal situação, o que é inadmissível, especialmente em um momento onde a preocupação com o aperfeiçoamento das raças estava na ordem do dia. Sparano exalta a criação da eugenética, eugenésia ou eugenismo. Conta que, desde 1912, congressos e associações tinham sido fundados para tratar da questão da produção, conservação e melhoramento da espécie humana. Acrescenta que a eugenética se baseia no conhecimento das leis da herança recente e ancestral, nos preceitos da higiene, da terapêutica e da puericultura antes e depois do parto. Além disso, a experiência de cultivadores e criadores também tem sido relevante para a pesquisa sobre a obtenção de produtos sadios.

Considerando os princípios da eugenética, era preciso reverter os males causados pela educação feminina. O autor lembra que se diferenças foram estabelecidas entre homens e mulheres, isso ocorreu em virtude da falta de funcionamento adequado do organismo feminino. Não tendo as mesmas solicitações que o masculino, acabou sofrendo a atrofia de alguns órgãos. É por isso que as mulheres do campo, por exemplo, são diferentes das mulheres da cidade. Continuamente solicitadas a fazer trabalhos braçais, elas mantiveram um corpo mais forte. Da mesma forma, as mulheres de descendência nobre com elevada educação intelectual tornaram-se providas de um largo material de inteligência. Já que a mulher possui os mesmos órgãos que o homem, guardadas as diferenças do sexo, o problema era apenas de exercício das suas funções. Sparano (1916:34) ainda menciona que:

Não é o organismo feminino a causa de uma fraqueza de seu sexo, mas sim a viciada educação que se lhe dá, apagando funções e atrofiando órgãos e aparelhos.

Eduque-se conscientemente e cientificamente a mulher e ter-se-á expurgado o mundo de uma falsa desigualdade, que, sem uma reação imediata e urgente, criará raízes biológicas e atávicas com evidente malefício da própria humanidade. 
Sparano ainda argumenta contra aqueles que querem justificar a doutrina da diferença entre homem e a mulher a partir da biologia. Esta teoria é desqualificada em virtude do fato de que até mesmo os órgãos sexuais seriam homólogos. O autor recupera a similitude entre ovários e testículos, por exemplo, para tratar de uma aproximação física entre os dois sexos. Também discorda dos autores que consideram as mulheres mais suscetíveis às doenças do que os homens. Termina o seu estudo afirmando que não há bases firmes para a doutrina da inferioridade. E o mundo tem assistido, com a Guerra na Europa, como as mulheres têm sido capazes de preencher muitas funções originalmente consideradas como masculinas. Diz também que uma comparação entre os sexos não seria possível até que os homens dessem provas de que dispõem das mesmas faculdades que as mulheres, como a delicadeza, a paciência, a finura e a meticulosidade, além de uma maior fortaleza de ânimo que as faz resistir com mais bravura à dor.

A relação entre a necessidade de educação da mulher, que reverte em uma maior igualdade perante o homem, e o bem da espécie e do país, aparece de forma ainda mais nítida na conferência proferida por Antonio Epaminondas de Gouveia, na Academia Nacional de Medicina, em 28 de agosto de 1922. ${ }^{14}$ A palestra se intitulava "A missão social do médico e da mulher no Brasil". A questão tratada foi definida pelo autor como a sagrada missão da classe médica naquele momento histórico em que se colocava como imperioso o esforço nacional de supressão dos focos de doença $e$ da promoção do povoamento útil e proveitoso do país. Nesse projeto, a educação da mulher é vista como absolutamente fundamental para a evolução do Brasil:

Outro fator importantíssimo na evolução social do Brasil futuro é a mulher, que deverá representar um papel supernal na nossa ascensão física e moral. Mas, para que a mulher brasileira realize este ideal nacional, precisamos rever os nossos cânones em matéria de educação feminina, no sentido de uma instituição mais liberal, ou menos desumana, atribuindo à mulher maior capacidade civil, e franqueando o trânsito às suas possibilidades intelectuais, de forma a harmonizar-se com eqüidade o concurso dos sexos na confecção do nosso progresso. Deixemos à margem da estrada o prélio bizantino, em que têm pelejado até doutas gentes, na faina exaustiva de provar com exóticas cubagens cerebrais, $e$ sofismas servidiços, surrateados da Anatomia e Fisiologia, a fantasiada superioridade do homem sobre a mulher. (Gouveia, 1922:14) 
Gouveia faz referência a Tito Livio de Castro quando afirma que a mulher estaria em uma posição atrasada em decorrência da atrofia do seu cérebro, que tinha sido muito pouco utilizado. Acrescenta que a mulher não deve ser considerada nem inferior e nem superior ao homem, mas, sim, seu equivalente. Diante dessa declaração, faz questão de esclarecer que não tem a intenção de se juntar às fileiras do 'feminismo radical', mas considera que um 'feminismo discreto e oportunista' faria grande bem ao país. Essa observação já dá uma idéia de que as preocupações do autor com a equivalência entre os sexos tinham como objetivo antes o progresso da nação do que os direitos das mulheres. No trecho que segue, Gouveia (1922:14-15) introduz o tema do papel da mulher em relação à eugenia:

Eu antevejo, com imensa alegria, o que será a mulher brasileira quando o seu diamantino espírito for melhor trabalhado pelos ideais modernos de progresso, de patriotismo inteligente e prático; quando ela sair desta escravidão de pensamento, tornado-se apta para a nova função social de sacerdotisa da Eugenia, que muito se há de beneficiar com a sua superior inspiração natural. Porque a mulher brasileira, dizem doutos psicólogos, possui uma organização original. E quando as suas energias mentais receberem uma educação superior, uma cultura sabiamente orientada, pela alta influência que ela exerce na família, poderá obter surpreendentes resultados. Cai a lanço dizer-vos que julgo um dever inadiável tirarmos dos olhos da mulher brasileira as escamas que lhes ocultam os graves perigos que espreitam o seu corpo e a sua alma. Quantas pobres senhoras padecem os mais bicais martírios (...). E esta tortura toda é, muita vez, o fruto da ignorância da profilaxia e da razão etiológica das moléstias contagiosas (...). E por isto ficam peiadas, inermes, 'ungidas do martírio', condenadas ao holocausto ingrato, onde a saúde se consome e a beleza e a mocidade se esvaem no fumo do sangue corrompido. Que rebentos poderão brotar de um tronco assim deteriorado? Proteger a árvore e o fruto contra o assalto dos parasitas é grande e nobre fórmula sintática de higiene social. Se o nosso futuro depende, como pregam os entendidos, do aperfeiçoamento da raça dessangrada, para logo ressalta a necessidade de uma colaboração inteligente e leal entre os dois sexos na divina missão de reproduzir a espécie.

É preciso chamar a atenção para a ameaça, revelada pelo autor, da geração de rebentos doentes ou degenerados associada com a falta de educação da mulher, especialmente no que se refere às doenças e à compreensão da sua missão de procriadora. Em contrapartida, se convertida ao saber médico, a mulher pode se transformar na sacerdotisa da eugenia. Nesse ponto, há uma valorização das capacidades intrínsecas à mulher, como 
a sua superior inspiração natural. Através da eugenia, ela pode passar de grande responsável pela transmissão de males e pelo atraso evolutivo da espécie à sua grande benfeitora. Mas, para isso, deve se submeter a cumprir as orientações prescritas pelos médicos que, notavelmente, dizem respeito à maternidade. É significativo que o texto de Gouveia fale, por um lado, da necessidade de instruir as mulheres para cumprir essa função, enquanto, por outro, reforça a idéia de que a maternidade é algo que já está inscrito no corpo e mesmo no coração da mulher. Ou seja, ela naturalmente é destinada para a procriação, não há como negar o fato. Mas, nem sempre tem feito isto da maneira adequada, aquela concebida pelos médicos. Além disso, a maternidade passa então a ser associada não apenas com os desígnios da natureza, mas também com os da pátria. Nesse sentido, o autor afirma:

O instinto do coração já deve tê-la avisado de que é chegada a hora de se cumprirem os altos destinos da Pátria. Mas, para que ela possa bem desempenhar seu papel no grande drama social de nossa formação, é preciso que a sua educação seja refundida e modernizada, a fim de que ela conscientemente se incorpore na abstração geral de sua raça. (p. 16)

Isso implicaria que a mulher fosse instruída de acordo com os padrões eugênicos. ${ }^{15}$ Ela não poderia ser promovida a sacerdotisa da eugenia se não conhecesse o assunto. E ainda não sabia sequer que essa ciência social aposta na evolução futura da raça. Desconhecia as doenças e o modo de preveni-las. Cabia à medicina transformá-la para procriar, alimentar e educar filhos saudáveis para a raça e para a pátria:

Ensinemo-lhe a divina floricultura da infância, esta sagrada jardinagem, cuja prática envolve a mulher num halo de santidade e de beleza astral. Ensinemo-lhe a decifrar na Eugenia o mistério das gerações robustas e fortes, espécie de aristocracia biológica, que há de levar o Brasil aos píncaros da glória e do primado entre os povos. Convençamo-la por uma educação especial de que a sua mais comovedora lindeza é quando alimenta nos seios fartos e sadios os rebentos floridos dos seus cândidos amores. (p. 24) ${ }^{16}$

A ênfase na educação da mulher para a maternidade é o principal ponto da palestra realizada pelo dr. João Mauricio Moniz de Aragão ao microfone da Rádio Jornal do Brasil, no contexto das comemorações do Dia da Criança. Aragão era chefe do Primeiro Distrito de Puericultura do Distrito Federal e vice-diretor da Pró-Matre. A palestra se intitulava 
"A mulher e a raça". O início é dedicado ao reconhecimento de que todos objetivam o bem da criança, mas por motivos diferentes, mais referidos a sentimentos individuais ou patrióticos:

Levados pela solidariedade humana, uns contemplam a criança como parcela do seu ser, carecedora de amparo e de carinho; outros guiados por sentimentos diferentes, altamente patrióticos, consideram-na como força econômica, potencial formidável de onde há de sair a grandeza do Brasil. Na sinceridade dos seus propósitos todos seguem a trilha benfazeja de amparar a criança. E amparando-a, trabalham pelo futuro da Pátria. Depende a hegemonia de um país do valor econômico e do poder dos seus filhos. Para tanto é necessário homens fortes, produto de uma juventude robusta, resultado de uma infância sadia. (Aragão, 1941:341)

A puericultura é novamente citada. Mas dessa vez sua definição é mais ampliada. Segundo Aragão, a puericultura abrangeria um vasto campo de atividades que começaria com o período pré-concepcional, passando pelo cuidado com o embrião através da higiene pré-natal e chegando ao atendimento da criança desde o nascimento até a adolescência. Porém, tudo tem de começar com o amparo às futuras mães, que devem ser ensinadas a cumprir o seu papel da melhor forma possível, de acordo com as orientações da medicina e visando ao progresso do país. É o que indica o trecho que segue:

Da mulher, da mulher que sabe ser mãe depende o futuro de uma nação. $O$ destino confiou à mulher a alta incumbência de perpetuar a espécie; é indispensável prepará-la convenientemente para o desempenho de tão nobre missão, colocando-a em condições físicas e mentais adequadas, pois só assim poderá gerar seres sadios e conduzi-los com sabedoria, através os instantes tormentosos e difíceis da existência.

No preparo da mulher reside incontestavelmente uma das grandes forças de que dispõe a puericultura para construir uma raça sã. Ninguém semeia em terra safara. Todos preparam a terra em busca de boa colheita. Assim devem fazer os puericultores. É preciso preparar toda mulher em idade de conceber, para a alta missão de perpetuar o homem. Assim os produtos saídos das suas entranhas serão sadios e fortes e, aqui fora, criados num ambiente propício ao seu desenvolvimento, formarão uma raça poderosa, orgulho de uma nação livre e civilizada. (Aragão, 1941:341)

Para tanto, é preciso preparar o corpo e o espírito da mulher desde o momento que chegou à puberdade. Deve-se procurar constituir um físico 
robusto, ministrar uma educação adequada, explicar o papel que tem na sociedade. Preparar o físico implica em corrigir os defeitos, combater as infecções, proporcionar um ambiente próprio ao șeu desenvolvimento e afastar as más condições de higiene e vícios alimentares. Quanto à educação, Aragão (1941:342) afirma:

É indispensável educar a mulher dentro de normas rígidas, afastandoa da falsa moral que domina sob a espetacular rubrica de 'maternidade consciente'. Dar-lhe os conhecimentos necessários para que possa compreender o valor e a significação do papel que desempenha de eternizar a espécie. Mostrar e ensinar como resolver os problemas que hão de surgir no cumprimento de sua árdua missão. Esclarecer como deve proceder para que tenha uma gravidez normal, um parto feliz e um filho são. Ministrar ensinamentos para que possa criar o filho sadio, dentro das sábias normas da puericultura e educá-lo dentro dos modernos preceitos da higiene mental. Modelar seu espírito segundo as necessidades imperiosas à sua situação de futura mãe, de mãe e de educadora.

Desde de que sua educação seja cuidada dessa forma, a mulher não vai fugir do seu dever primeiro:

Perfeitamente preparada dentro dos duros princípios da puericultura, cuidadosamente educada para o papel que tem de representar na sociedade, honestamente esclarecida sobre as etapas que tem de atravessar, com os conhecimentos indispensáveis para atender às necessidades do ser que há de sair de suas entranhas, a mulher jamais fugirá aos deveres sagrados da maternidade. (p. 342)

Quando a mulher é amparada dessa forma pelos médicos, a criança nascerá forte e sadia, e se for vigiada por um puericultor competente se tornará um adolescente robusto, um jovem forte e um homem vigoroso. $\mathrm{E}$ o palestrante conclui, enfatizando que "Uma plêiade de homens sadios constitui a grandeza de um povo e o poderio de uma nação" (p. 342).

\section{A Maternidade e o Futuro da Nação}

Para finalizar este estudo, não poderia deixar de fazer referência à especificidade da chamada era Vargas, momento em se percebe uma redobrada valorização da maternidade. Particularmente alguns ramos da medicina, como a ginecologia e a obstetrícia, contribuiriam bastante para esse processo, na medida em que empreenderam iniciativas de uma maior aproximação com o Estado, em prol da defesa da maternidade e da 
infância. ${ }^{17}$ Mas, como veremos, novamente seriam as preocupações em torno do futuro da nação que estariam à frente das iniciativas. ${ }^{18}$

Se recorrermos aos Annaes Brasileiros de Gynecologia, por exemplo, vamos encontrar várias passagens ilustrativas, como é o caso do editorial do segundo volume de 1936. O texto começa citando a circular emitida por Getulio Vargas no Natal de 1932, qualificada como "uma prece em prol da infância no Brasil, um grito de patriotismo, que criou para o governo brasileiro uma obrigação moral e um compromisso de honra". ${ }^{19} \mathrm{Na}$ circular, o presidente dizia que:

Os poderes públicos têm no amparo à criança, sobretudo quanto à preservação da vida, à conservação da saúde e ao desenvolvimento físico e mental, um problema de maior transcendência, chave da nossa opulência, principalmente em nossa terra, onde, mais talvez do que nas outras, se acumularam fatores nocivos à formação de uma raça forte $e$ sadia. (Annaes Brasileiros de Gynecologia, 326, 1936) ${ }^{20}$

Os médicos já percebiam em Vargas os ecos das teorias sobre raça e das concepções sobre a importância da criança que tomavam maior vulto na época. Era preciso naquele momento transformar cada vez mais esse discurso em ações efetivas que deveriam, preferencialmente, estar sob o comando dos especialistas em obstetrícia, ginecologia e puericultura.

O editorial fala ainda das altas e crescentes taxas de mortalidade infantil no Rio de Janeiro e no resto do país. No mesmo parágrafo, são exaltadas as iniciativas em curso nos Estados Unidos, que visavam a proteger a maternidade e a infância, a partir de propostas dos próprios presidentes americanos. Ou seja, o Brasil estava no caminho certo desde que levasse à pratica as idéias que o próprio Vargas proferia. Após a Circular do Natal de 1932, foi realizada a primeira Conferência de Proteção à Infância e foi criado o Departamento da Maternidade e Infância. Estes eventos assinalariam um marco na proteção à criança e à mãe brasileiras.

Destaca-se ainda, no editorial, a noção de que a saúde pública não deve ser exclusivamente polícia sanitária ou burocracia mas, prioritariamente, profilaxia e assistência. E transcreve-se a carta de Olinto de Oliveira, chamado de "o grande patriota", em função de sua dedicação aos serviços de assistência à maternidade e à infância, dirigida ao deputado, e também médico, Xavier de Oliveira. Esse último apresentava no momento um projeto à Câmara dos Deputados em prol da defesa das mães e crianças do país. Na carta, mais uma vez os argumentos para a proteção 
da maternidade e infância giravam em torno do "renascimento da nossa raça" (Annaes Brasileiros de Gynecologia, 328, 1936).

As referências que associavam maternidade, infância, raça e nação se sucedem nos periódicos médicos. O ano de 1940 aparece com destaque especial, em virtude de acontecimentos significativos. Esse ano pode ser considerado um marco na aproximação de médicos, em particular obstetras e ginecologistas, com o Estado. O editorial do volume nove dos Annaes Brasileiros de Gynecologia (1940) menciona e elogia um decreto-lei emitido por Vargas nesse ano:

O Presidente da República acaba de decretar as medidas necessárias a um vasto programa de assistência à maternidade, à infância e à adolescência. De fato, o decreto-lei número 2.024 de 17 de fevereiro de 1940, fixa as bases da organização da proteção à mulher mãe e à criança, atendendo, dessa forma, a um alto imperativo de grande alcance para a nossa pátria. Esse o motivo pelo qual estes Anais que têm como parte de seus propósitos, cooperar para esse mesmo fim, resolverem dedicar estas páginas ao registro da medida governamental que vai ao encontro de uma necessidade vital para o Brasil, vasta região do globo à espera de uma população numerosa, mas nas melhores condições de higiene possível, para não continuar a ser o vasto hospital, a que se referia o saudoso Prof. Miguel Pereira. (Annaes Brasileiros de Gynecologia, 161,1940)

O tom do discurso é o de apresentar o momento como o ápice de um processo de luta em prol da infância e maternidade que teria começado dentro da medicina. Após o trecho citado, o editorial resume a história desse percurso, tomando como ponto inicial uma conferência proferida por Arnaldo de Moraes em 1930 na Sociedade de Medicina e Cirurgia. A conferência versava sobre o "Problema Pré-natal" e mereceu "valioso aplauso" de Olinto de Oliveira, o puericultor que pouco depois seria nomeado para chefiar a Diretoria da Maternidade e Infância. Oliveira, considerado como pessoa de absoluta confiança de Vargas, teria, de forma tenaz e competente, realizado uma série de medidas que agora estariam consubstanciadas no decreto-lei.

Destacam-se também os debates ocorridos na Academia Nacional de Medicina e a formação de uma comissão que deveria apresentar sugestões ao governo federal sobre a questão da mortalidade materna. A comissão, composta por Arnaldo de Moraes, Octavio de Souza e João Camargo, em novembro de 1939 apresentou o seu parecer. No documento, ao lado de medidas relativas à assistência propriamente dita, também são tratadas 
questões referentes ao ensino da clínica obstétrica e à formação de parteiras. Defendia-se o ensino da obstetrícia de maneira mais eficaz, o que implicava a freqüência de dois anos de curso e a assistência obrigatória a vinte partos pelo menos, além de uma maior valorização dessa especialidade no currículo médico.

As escolas de parteiras são apresentadas como uma necessidade em todas as grandes cidades do país. As escolas deveriam ter maternidades próprias, revalidar o título das profissionais a cada cinco anos, prever estágios compulsórios e proibir a clínica para aquelas que exorbitassem de suas funções. Essas medidas, em última instância, justificam-se pela grande responsabilidade desses profissionais, cuja formação deve ser muito bem controlada, face às aspirações do Estado: "Puericultores e obstetras não se improvisam, é preciso prepará-los para que possam os profissionais a que vão caber os altos encargos de velar por mães e filhos, estar à altura das altas finalidades das medidas governamentais" (Annaes Brasileiros de Gynecologia, 161,1940).

O editorial menciona ainda a exposição feita pelo ministro da educação e saúde, Gustavo Capanema, durante a criação do Departamento Nacional da Criança. Capanema teria deixado nítidos os propósitos governamentais de assistência, pesquisa e justiça social, além de reforçar a necessidade de despertar no país uma atmosfera de interesse para os problemas vitais da maternidade e da infância. O Departamento recémcriado é descrito como um "verdadeiro farol de grande luminosidade" por meio do qual o país socorreria a mulher mãe e a criança, desvalidas e desamparadas (Annaes Brasileiros de Gynecologia, 161, 1940).

No ano de 1940 aconteceria ainda o Primeiro Congresso de Ginecologia e Obstetrícia, que pode ser visto como uma ocasião singular em termos da aproximação dessas especialidades médicas com os programas do Estado e de um relativo aumento de seu prestígio. O editorial do volume 10 dos Annaes Brasileiros de Gynecologia (agosto de 1940) é dedicado ao anúncio da realização do Congresso no mês seguinte. Em primeiro lugar, informase que o evento é promovido pela Sociedade Brasileira de Ginecologia, ${ }^{21}$ que tem procurado "aprimorar os conhecimentos científicos da ginecologia e da obstetrícia", debatendo problemas relativos ao ensino e ao exercício clínico, através da congregação de médicos de todo o país por meio de reuniões que agora tomam maior vulto no Primeiro Congresso. ${ }^{22}$ A importância da Sociedade e do encontro teria sido reconhecida também 
pelas autoridades governamentais. O editorial menciona que o próprio presidente Vargas e o ministro Capanema "imediatamente hipotecaram seu valioso prestígio, amparando essa reunião científica, certos da grande vantagem que, para nossa cultura e aperfeiçoamento, representa, prélios intelectuais de tal natureza" (Annaes Brasileiros de Gynecologia, 10:127, 1940). Participantes argentinos, uruguaios e chilenos foram convidados com o apoio do governo, transformando o evento em um acontecimento internacional e prestigioso para os médicos e para os seus patrocinadores.

Como presidentes de honra foram escolhidos Vargas e Capanema, além de Oswaldo Aranha (ministro do Exterior) e Henrique Dodsworth (prefeito do Distrito Federal). Entre os vice-presidentes de honra, estavam Olinto de Oliveira (diretor do Departamento Nacional da Criança), Jesuino de Albuquerque (secretário geral de Saúde do Distrito Federal), Fróes da Fonseca (diretor da Faculdade de Medicina), Aloysio de Castro (presidente da Academia Nacional de Medicina), Manuel de Abreu (presidente da Sociedade de Medicina e Cirurgia) e Pinheiro Guimarães (presidente do Colégio Brasileiro de Cirurgiões) (Annaes Brasileiros de Gynecologia, 10:127-128, 1940).

Entre os temas escolhidos para o evento, estava o "Aspecto social da assistência obstétrica", considerando o período pré-concepcional, pré-natal, a mortalidade materna, a mortalidade neonatal e a assistência social propriamente dita. ${ }^{23}$ Comenta-se que esse tema era de especial interesse do governo, que tem "tomado medidas concretas e se empenhado na proteção da maternidade e da infância", um "problema de tão largo alcance para a nossa nacionalidade" (Annaes Brasileiros de Gynecologia, 10:128, 1940). Novamente, as palavras do ministro Capanema são citadas, dessa vez as proferidas por ocasião da inauguração das Jornadas Carioca-Paulistas de Obstetrícia e Ginecologia, em que ele também esteve presente. No discurso, o ministro afirmou que o governo esperava dos ginecologistas do Brasil a cooperação para a solução das dificuldades relacionadas ao futuro do país.

O desejo de progresso, a fé no trabalho, o amor pela ciência e o patriotismo são identificados como os princípios norteadores dos congressistas. E entre os objetivos destacava-se a promessa de demonstrar que os progressos da ginecologia e da obstetrícia visavam à proteção à saúde e à vida da mulher, de modo a garantir a produção de filhos sãos. Dessa forma, o "verdadeiro celeiro do país" seria preservado e o seu bem mais valioso, que é o seu "capital humano", aperfeiçoado (Annaes Brasileiros de Gynecologia, 10:129, 1940). As especialidades médicas dedicadas à mulher 
e à reprodução assumiam como meta fundamental melhorar a produção de cidadãos e dessa forma se constituíam como aliadas do Estado. A defesa da soberania e do futuro da nação envolvia o 'aperfeiçoamento' de sua população. Nesse quadro, as idéias eugênicas de melhoria da raça, de forma mais ou menos explícita, eram conjugadas com a valorização da natalidade e uma preocupação médica mais acentuada com a mãe e a criança.

Essas características podem ser ilustradas, por exemplo, pelas palavras de Arnaldo de Moraes na introdução do livro Propedêutica Obstétrica, publicado originalmente em 1924 e que em 1937 já estava na quinta edição. O trecho a seguir ilustra a amplitude das funções do obstetra e a aproximação com a eugenia, além de ressaltar a preocupação com as crianças:

De ação tão ampla, confundindo-se com a atuação do eugenista, do puericultor, do pediatra, do higienista, do político e do patriota, compreende-se o valor do obstetra moderno. A este cumpre investigar as causas da esterilidade e removê-las, bem como os motivos da interrupção das gestações pregressas e evitá-la pelo tratamento adequado; fazer a assistência à prenhez, afastando pela terapia e pelos cuidados higiênicos (regime dietético, profilaxia das situações anormais do feto etc.), todas as causas capazes de perturbar a gestação ou provocar a distocia; assistir ao parto, com o conhecimento perfeito da fisiologia do mesmo, para ajuizar com segurança da sua marcha e da oportunidade da intervenção, sobrevindo a distocia. Nessa oportunidade tem que se mostrar habilitado a resolvê-la, ora com simples operação obstétrica, ora com intervenções cirúrgicas algumas de mais alta importância (...); e ainda, passada essa fase, que assinala o término da prenhez, cuidar do recémnascido, orientando o aleitamento e impedindo ou removendo as causas que o prejudiquem, verificando lesões (...) e vícios de conformação (...) e corrigindo-os. (Moraes, 1937:17)

No mesmo trabalho, Moraes lamentava que os responsáveis pelo país considerassem com displicência e com banalidade o ato da parturição e a puericultura. Segundo ele, a assistência materna no Brasil e mesmo na capital carecia dos sentimentos de humanidade e patriotismo. A proteção da mulher mãe e do fruto humano reclamava maior atenção por parte do governo. Já os médicos se esforçavam cada vez mais no sentido de cuidar para que a reprodução transcorresse da melhor maneira possível, tanto através do estudo do problema quanto da assistência que prestavam.

A estreita relação entre a atenção médica dada à mulher e a consideração das influências sociais pode ser vista ainda em um interessante artigo editado também em 1941. Nele, o ginecologista e obstetra, então 
professor da Faculdade de Medicina do Rio de Janeiro, Assad M. Abdenur tratava exatamente dos "Aspectos da ginecologia social". Na tradição da medicina social viria a ginecologia social, que estuda todas as modalidades mórbidas ginecológicas que dependam das condições sociais da mulher. Seria a parte da medicina social dedicada ao sexo feminino. ${ }^{24}$ Essa disciplina se fundamentaria na relação com outras ciências, entre as quais estariam a medicina clínica, a endocrinologia, a política, a medicina social, a psicologia, a psiquiatria, a profilaxia, a higiene e a eugenia. No caso desta última, o autor destaca a importância da esterilização.

Abdenur afirma, em seguida, que foi somente com o Estado Novo que a proteção da mulher e da infância começou a tomar vulto. Depois fala da antropogeografia, que se resume na idéia da que o país era ainda muito pouco povoado, o que implicaria a necessidade de uma política médico-social que considerasse sobretudo a mulher: "À fração feminina deve caber grande parte das medidas de proteção. Pela importância de suas funções geratrizes, e ser o primeiro agente protetor da infância, merece os desvelos de quem vise índice de natalidade qualitativa e quantitativamente bom. Surge daí a razão de ser de um ponto de vista eugênico" (Abdenur, 1941:521).

$\mathrm{O}$ autor define como objetivos da ginecologia social a proteção à maternidade (higiene pré-natal, assistência ao parto e assistência à primeira infância), despistagem da lues e outros males venéreos, campanhas contra o câncer, a propaganda de uma alimentação racional, a 'patologia do trabalho feminino', a terapêutica da esterilidade, a repressão ao aborto criminoso, a higiene psíquica ou mental do sexo feminino etc. Teria como meios para realizar tais fins a técnica, a propaganda e legislação sanitária, a filantropia, a luta contra o pauperismo e a estatística.

O Primeiro Congresso Brasileiro de Ginecologia e Obstetrícia aconteceu entre 8 e 15 de setembro de 1940 no Palácio Tiradentes, sob os auspícios do governo federal. A sessão inaugural foi presidida por Gustavo Capanema, que proferiu um discurso de aproximação entre os objetivos do governo e os profissionais dedicados à ginecologia e à obstetrícia. O pronunciamento inicia com congratulações e elogios ao Congresso e à Sociedade Brasileira de Ginecologia, uma instituição que teria o mérito de reunir tão ilustres médicos como o seu presidente, Arnaldo de Moraes. Em seguida, o ministro passa para o tema central da palestra, que era o empenho nacional na assistência à maternidade e à infância, visando ao progresso da pátria: 
É a obra nacional de proteção à maternidade e à infância, colocada entre as primeiras preocupações governamentais de nosso país. Nós, brasileiros, temos um programa de enormes realizações no terreno da economia e no terreno da cultura. Queremos tornar nossa pátria, cada vez mais, numerosa na população, forte e segura no espírito, empreendedora, honrada, ilustre.

Mas este engrandecimento está, sob todos os seus aspectos, condicionado à qualidade do nosso homem, ao seu valor biológico, ao seu valor moral e intelectual. E é fora de dúvida que a boa qualidade do homem só pode decorrer da geração sadia e forte, a qual é em grande parte um resultado da saúde materna, da maternidade vigorosa e perfeita. (Annaes Brasileiros de Gynecologia, 10:278-279, 1940)

O ministro ainda salienta que os temas a serem debatidos no Congresso estão estreitamente relacionados com esse grande problema nacional e por isso o governo dá apoio total ao encontro. Por fim, chama a atenção para os sentimentos de solidariedade e patriotismo que motivam os médicos presentes e felicita os membros estrangeiros (Annaes Brasileiros de Gynecologia, 10:279, 1940). Arnaldo de Moraes agradece as palavras do ministro e o empenho do governo na realização do evento.

A sessão na qual se discutiu o "Aspecto social da assistência obstétrica" teve como presidente o Diretor do Departamento Nacional da Criança, Olinto de Oliveira. Seu discurso de abertura lembrou mais uma vez o grande interesse do presidente Vargas pela proteção à infância, expresso na criação do Departamento que abrangia também a proteção à maternidade. O Departamento, por meio de seus delegados, tinha como tarefa orientar e fiscalizar todos os estabelecimentos destinados à assistência e recolher informações que serviriam como subsídios para a ação do governo federal. Olinto de Oliveira faz referência ainda a José Bonifácio, que em 1823 teria exigido o amparo à mulher trabalhadora durante a prenhez. Em seguida, o presidente do Congresso, Arnaldo de Moraes, leu uma proposta de voto de aplauso ao governo de São Paulo pela criação e organização do Serviço de Higiene e Assistência pré-nupcial, pré-concepcional e pré-natal.

Passou-se, então, à apresentação do relator oficial, J. C. Lascano, vindo de Buenos Aires. O médico argentino faz um resumo histórico da assistência obstétrica, tomando como marco o século XVII, quando as parteiras perdem prestígio e os médicos passam a atender as parturientes. Mas afirma que a fase verdadeiramente oficial da obstetrícia só começou 
em fins do século XIX, quando deixou de ser uma caridade para se tornar um direito. Surgiram nessa ocasião as primeiras leis de proteção às trabalhadoras grávidas. Lascano acrescenta que, introduzidas em quase todos os países e ampliadas depois da grande guerra, tornaram-se particularmente complexas e eficazes na Alemanha depois do regime nazista, na Espanha e nos países escandinavos. A Conferência Internacional do Trabalho, realizada em Washington em 1919, tinha fornecido as bases para as legislações sobre trabalho, abrangendo também a 'mulher-mãe'. Além disso, toda a medicina vinha tomando um aspecto social, um movimento no qual a obstetrícia constituía parte importante (Annaes Brasileiros de Gynecologia, 10:326-327, 1940).

Nos Anais do Primeiro Congresso Brasileiro de Ginecologia e Obstetrícia (1942), temos o relatório apresentado pelo dr. Octavio de Souza sobre o tema. O médico explica que o aspecto social da assistência obstétrica implica fundamentalmente a atenção aos direitos da mulher na gravidez e no puerpério, como o repouso e o seguro materno remunerado. Faz um histórico das iniciativas a respeito, que congregavam as preocupações dos médicos e do Estado. Lembra que em 1917 surgiu a primeira lei que interditava o trabalho feminino nos quatro primeiros meses após o parto. Assinala como um marco importante a conferência de Fernando Magalhães no Primeiro Congresso Brasileiro de Higiene, em 1923, que chamava a atenção para a necessidade de aprimorar a legislação referente à proteção à maternidade. Defende que o Estado deve atuar sempre no sentido de favorecer a criatura que propaga a espécie e contribui com a sua parcela para a grandeza do país. Demonstra, através da referência às leis, que o amparo à maternidade vinha, gradualmente, sendo feito, especialmente a partir de 1932. ${ }^{25}$ A legislação a partir dessa data mostraria um claro interesse do presidente Vargas no assunto. O decreto $\mathrm{n}^{\mathrm{e}} 21.417-\mathrm{A}$, de 17 de maio de 1932, regulava as condições de trabalho nos estabelecimentos industriais e fabris e amparava a mulher operária em gestação. ${ }^{26}$ No mesmo ano, a já citada mensagem de Natal do presidente solicitava aos técnicos do Estado:

métodos e diretrizes a seguir para favorecer a auxiliar todas as instituições seriamente empenhadas em promover o bem-estar, a saúde, o desenvolvimento e a educação da criança, desde antes do nascimento, pela assistência à Maternidade, até a idade escolar e adolescência, proporcionando-lhe os subsídios indispensáveis à promulgação de leis e regulamentos, tendentes a realizar uma proteção eficaz à infância, como 
segurança de êxito. (Anais do Primeiro Congresso Brasileiro de Ginecologia e Obstetrícia, 73-74, 1942)

Em 1934, a Constituição, então decretada, estabelecia no artigo 141 a obrigatoriedade do amparo à maternidade e à infância. No mesmo ano, o município do Rio de Janeiro regulamentava, pelo decreto $\mathrm{n}^{2} 4.785$, o repouso e indenização por meio de licença remunerada a professora ou estagiária em estado de gestação. A Constituição de 1937 também considerou o tema, prevendo no artigo 137 a assistência médica ao trabalhador e à gestante, assegurando a esta, sem prejuízo do salário, um período de repouso antes e depois do parto. Em 1938, outro decreto municipal estendia a todas as funcionárias os benefícios concedidos às professoras. O estatuto do funcionalismo público estabelecia em 1939 que a funcionária gestante teria direito a uma licença remunerada de três meses. Mais uma vez no Natal do mesmo ano, Vargas declarava o interesse do governo em promover a proteção à maternidade e à infância. ${ }^{27}$

Diante desse panorama que provaria o interesse do governo nas mães e crianças brasileiras e sua implicação no próprio futuro da nação, só cabia aos médicos o mais pleno apoio e desejo de colaboração. Em função disso, o Primeiro Congresso Brasileiro de Ginecologia e Obstetrícia termina a sessão dedicada ao aspecto social da assistência obstétrica votando uma moção de louvor e incentivo ao presidente Vargas, pelas constantes e acertadas medidas em favor da maternidade.

Entre as medidas tomadas pelo governo, estavam aquelas que visavam a promover, através de comemorações e concursos, a valorização da infância. Prêmios em favor da amamentação (Anais do Primeiro Congresso Brasileiro de Ginecologia e Obstetrícia, 82, 1942) e concurso de robustez entre bebês eram alguns desses eventos. O Brazil Medico de 1941 dedicou várias páginas ao relato das comemorações do dia da criança (25 de março). Todos os eventos na capital tinham sido presididos pelo médico e militar Jesuino de Albuquerque, secretário de Saúde e Assistência do Distrito Federal que, na opinião da revista, dava provas de seu patriotismo, e "interesse e zelo na formação do futuro homem potencial, brasileiro" (Brazil Medico, 245, 1941). Essa secretaria tinha recentemente criado (em 1940) o Departamento de Puericultura, que inaugurava na ocasião três cozinhas dietéticas ou lactários, que forneceriam três mil mamadeiras diárias. $O$ objetivo era diminuir a mortalidade infantil, que tanto causava prejuízos à "força viva da nação". O Dia da Criança foi também muito comemorado 
pelas associações médicas. A Sociedade de Medicina e Cirurgia, por exemplo, se reuniu em sessão extraordinária. Algumas conferências lá proferidas são bastante reveladoras das posições adotadas pelos médicos. $\mathrm{O} d r$. Oswaldo Boaventura disse que a Sociedade tinha naquele momento um ensejo "quase santo" e que ele próprio "hipotecava todas as ternuras de seu coração em prol da campanha em favor da criança brasileira pois que ela, cuidada, será no futuro a fonte primeira de todas as energias exaltadoras da Pátria" (Brazil Medico, 246-247, 1941).

O dr. Carlos de Abreu proferiu uma longa conferência, na qual exaltava o início de uma nova era para a criança brasileira. Explicava que o Dia da Criança tinha por objetivo incentivar a opinião pública a se conscientizar da necessidade de dar mais atenção à gestante pobre e à infância desamparada. E dizia sobre o papel dos médicos em relação à quantidade e à qualidade da raça:

Cabe assim a todos os brasileiros de boa vontade e principalmente a nós, médicos, respondermos a esse incentivo superior dando à nossa Pátria, pelo muito que dela recebemos, a nossa cooperação esforçada, ampla, humana, no sentido de podermos elevar o número e o valor da nossa população numa benemérita obra social, de formação quantitativa e qualitativa de nossa raça. (Abreu, 1941:246-247)

Abreu salientava também como o chamado problema demográfico prejudicava o país. E exclamava que a meta de reversão da situação tinha que necessariamente começar com as mulheres. Através da assistência às mães poder-se-ia chegar a uma raça mais forte:

Para elevarmos o nível orgânico de nossas populações com o humaníssimo e patriótico fim de criar uma raça mais forte e mais feliz devemos começar a tarefa pelo início, ou seja, assegurando às mães as condições que favoreçam a concepção, a gestação, o parto, o puerpério e a criação de seus filhos num ambiente que permita ao ser a sua elevação perfeita, física, moral e intelectual. (p. 246-247)

A proteção à mulher trabalhadora e a assistência médica, que passavam cada vez mais a ser defendidas pelos médicos e que estariam motivando atitudes do governo, tinham como foco a capacidade de produzir filhos saudáveis para a pátria. Na medida em que passava a ser cada vez mais responsabilizada pelo futuro do 'capital humano' da nação, a mulher conquistava uma nova atenção e uma nova percepção por parte dos médicos, especialmente aqueles dedicados à reprodução. 
Carlos de Abreu também enfatiza a importância da puericultura, a ciência aplicada ao conhecimento e cuidado da criança sã. A puericultura se distinguiria da pediatria, na medida em que esta se ocupava do cuidado da criança doente. O autor dá a entender que a puericultura implicaria em primeiro lugar o favorecimento do número de nascimentos. Comenta que, ao longo da história da humanidade, o cuidado com a criança tem sempre sido um sinal de progresso. Apenas os povos caducos, aqueles que desapareceram e aqueles que acreditavam que todos os lugares disponíveis na terra já estariam ocupados pensaram em limitar os nascimentos. $\mathrm{O}$ aumento da natalidade estaria na raiz de qualquer possibilidade de crescimento para a raça e para a nação. Seria o fator indispensável para que as preocupações eugênicas se tornassem iniciativas efetivas. Abreu (1941:252) comenta, com referência a isso, que:

Toda medida de ordem eugênica social exige que exista primeiro material humano em abundância que preencha o ritmo natural da vida. $O$ que resta é obra de justiça, amor e compreensão.

Os que estão têm o dever de preparar o caminho dos que vierem e somente assim poderemos culminar nas gerações fortes e sadias de um futuro próximo.

Seguindo o raciocínio do médico, um povo que se preocupasse com o futuro precisava incentivar os nascimentos de modo que pudesse melhorar a qualidade de sua raça. E para tanto era fundamental, em primeiro lugar, cuidar das futuras mães. A mulher se convertia em um sujeito importante para a nação, porque tinha a função de garantir a quantidade e, conseqüentemente, a qualidade dos seus cidadãos. As especialidades médicas dedicadas à mulher e à criança se aproximavam das propostas eugênicas e tentavam prever e administrar o advento do Brasil como uma grande nação.

A questão da raça, tão insistentemente citada, estava no centro dos debates, não apenas científicos, nas primeiras décadas do século XX. E o reforço da noção da necessidade natural da maternidade para a mulher também era atravessada pelas apreensões quanto ao futuro do país a partir das suas disponibilidades raciais. Afinal de contas, a mulher era percebida como a grande responsável pela procriação e também pela educação dos filhos.

E é a partir dessa perspectiva que os médicos vão passar a insistir muito na necessidade de educar a mulher para o bom cumprimento do seu destino natural. Mas é uma educação que, em primeiro lugar, pressupõe 
que ela precisa reaprender com a medicina o seu papel original. Entretanto indica que qualquer iniciativa no sentido de promover o 'desenvolvimento' da mulher envolve não o seu reconhecimento como sujeito, mas o que ela representa em termos da propagação da espécie e do progresso da nação. É a obsessão com o melhoramento da raça que viabiliza uma certa reconsideração da função feminina na sociedade, que implica não a mudança no sentido de assumir novos papéis', mas uma espécie de maior valorização do que representa, a partir da procriação e educação dos filhos. ${ }^{28}$ É porque se acredita que é preciso produzir mais e melhor que as mulheres devem ser mais bem educadas. Mas não se coloca em xeque a idéia de que ela serviria quase que exclusivamente para procriar. A diferença é que nesse momento a reprodução se transforma em um assunto de interesse público cada vez maior. Exagerando os contrastes, poder-se-ia dizer que, enquanto no século XIX a mulher é responsável pelos filhos, marido, família, nas primeiras décadas do século XX ela se torna a responsável pelo aprimoramento da raça e futuro da nação, uma missão sem dúvida ainda mais grave.

\section{Notas}

1 Não vou me deter sobre esse ponto porque, entre outras razões, existem vários estudos que têm mostrado como se configurava uma nova situação para muitas mulheres, especialmente a partir de sua participação mais significativa no mundo do trabalho pelo acesso à educação e a algumas profissões liberais. Em termos do debate público, as idéias feministas, com inúmeras variações, começavam a circular mais e a conquistar novos apoios, ao mesmo tempo que também eram mais combatidas tanto por intelectuais, médicos, autoridades, quanto por instituições como a Igreja Católica. Ver os trabalhos de Hahner (1980, 1994), Soihet (1997) e Maluf \& Mott (1998) para um quadro geral da inserção feminina no mundo público desde meados do século XIX. Sobre o trabalho feminino, recorrer a Rago (1987), Matos (1995), Pena (1981) e Moura (1989). Sobre cultivo do corpo e comportamento, ver Schpun (1999).

2 Uma série de trabalhos tem se dedicado sobretudo a mapear as políticas desenvolvidas na era Vargas quanto à família e ao trabalho da mulher e da criança. O livro recente de Duarte (1999) é uma boa contribuição nesse sentido. Ver também Besse (1989) e Fonseca (1993). Sobre a relação entre ciência e política, com destaque para a preeminência das idéias eugênicas, ver Stepan (1990).

3 A análise que segue introduz a questão da eugenia a partir do que aparece nos trabalhos médicos relativos à sexualidade e reprodução. Não pretendo me deter sobre 
a eugenia como um movimento mais abrangente, que mereceria um estudo bem mais cuidadoso, como o realizado por Stepan (1990). Para um panorama geral do desenvolvimento das idéias eugênicas em diversos contextos nacionais, ver Schneider (1982), Adams (1990) e Carol (1995).

4 Ver, entre outros, os seguintes trabalhos: Silva (1879), Xavier (1876), Coelho (1878), Corrêa Sobrinho (1905), Silveira (1908), Pax (1909), Pereira Junior (1911), Vita (1920), Freitas (1924) e Mattos (1929).

5 Seabra (1902) destaca a campanha empreendida por Erico Coelho a favor do divórcio no parlamento nacional.

6 Ver: Baptista (1900), Penteado (1905), Ferraz (1910), Mello (1912), Cunha (1914), Pontes (1914), Souza (1916), Moura (1917), Lima (1918), Ladeira (1919), Castro (1919), Lago (1921), Carvalho (1924), André (1924), Almeida (1925) e Gonçalves (1929).

7 A entrada da mulher no mercado de trabalho e um comportamento mais liberal eram percebidos como grandes ameaças à instituição da família a à própria sociedade. Besse (1989:187) sugere que esta impressão de ameaça estaria por trás da grande repercussão que os crimes passionais tiveram entre as décadas de 1910 e 1940. Para a autora, a campanha contra os crimes passionais empreendida nessa época permite visualizar uma apreensão mais geral a respeito da transformação das relações entre os sexos. Segundo ela: "O motivo pelo qual estes crimes começaram a ser considerados tão ameaçadores à sociedade era que eles simbolizavam a desagregação da família, e era exatamente a instituição da família que era encarada como o cimento necessário para proporcionar a estabilidade e a continuidade neste período de transformações perigosamente rápidas".

8 Léonard (1981), traçando as bases da aproximação entre médicos e Estado na belle époque francesa, destaca como fenômenos articulados deram origem a uma nova legislação trabalhista, a uma biopolítica da infância e à regulamentação do trabalho de mulheres e crianças. Para a medicina, que ratifica a diferença entre os sexos, a indústria destrói a saúde das mulheres, corrompe sua moralidade, afasta-as da maternidade e do aleitamento, prejudicando em última instância a raça. É nesse contexto que se valorizam abertamente os progressos da obstetrícia, da ginecologia, da pediatria e da puericultura. Criam-se inúmeras instituições e fortalece-se o ensino. E os grandes nomes dessas especialidades tornam-se celebridades internacionais. Instituições de proteção às futuras mães e às crianças, incentivando o aleitamento $e$ o cuidado higiênico se multiplicam. Médicos de direita e de esquerda se unem na condenação do aborto e das práticas neomalthusianas, além do 'relaxamento dos costumes' e dos 'interesses egoístas'.

9 A obra é prefaciada por Silvio Romero, que nos conta que Tito Livio de Castro morrera em 1890 com 26 anos de idade e "fora um mestiço que representou o máximo das raças cruzadas no Brasil". Romero também não poupa elogios ao estudo e considera o livro muito importante na área da antropologia e da ciência social, além de mencionar vários trabalhos que já citavam trechos da obra de Castro.

v Castro havia se doutorado em medicina no ano de 1889 com uma tese na área de psiquiatria denominada Alucinações e Ilusões.

"O 'médico demografista' forneceria os dados e elaboraria os projetos que o governo deveria colocar em ação. O governo não seria nada mais do que o demografista em ação. Castro lamenta que essa ciência ainda não tenha se desenvolvido no Brasil e o 
governo demonstrava pouco interesse na avaliação de sua população. Apenas mandava buscar imigrantes sem antes estudar o crescimento do número de seus cidadãos e problemas fundamentais como o aborto provocado, o infanticídio, o número de filhos ilegítimos, assim como o grau em que as doenças, especialmente as mentais, afetavam os brasileiros (Castro, 1893).

口 A idéia de desenvolvimento das mulheres, a partir da educação em prol da moralidade e da evolução da raça, não era exclusiva de Castro. A dra. Elizabeth Blackwell, a primeira mulher a se formar em medicina nos Estados Unidos em 1849, propunha que a equalização dos sexos e a educação da mulher eram de fundamental importância para a formação de indivíduos saudáveis e o aprimoramento da espécie. Krug (1996) ressalta que Blackwell, apesar de falar em igualitarismo entre homens e mulheres, não tinha pretensões feministas e também não estava interessada em dissociar o sexo da reprodução. Seus argumentos estavam subsumidos à preocupação com a degeneração e a evolução.

13 A partir do trabalho de Russett (1995) sobre o contexto de desenvolvimento de uma 'ciência da mulher' no mundo anglo-americano, percebe-se que os argumentos de Castro estavam bem concatenados com as teorias desenvolvidas em sua época.

4 É importante notar que essa conferência foi publicada no Boletim do Departamento Nacional da Criança no Brasil.

15 Bicalho (1993) descreve como o modelo de mulher proposto pela eugenia teve destaque no cinema dos anos 1920.

6 Stepan (1990) salienta que a eugenia trabalhou no sentido de valorizar a maternidade, especialmente para as jovens mulheres. Em contraste, muitos eugenistas brasileiros condenavam as feministas, exatamente porque elas representavam ameaças ao papel tradicional das mulheres.

17 Sobre as políticas públicas de defesa da maternidade e benemerência no Brasil, ver Mott (2001).

is O tema da relação entre o feminino e a nação é tratado por Schmidt (2000).

19 O uso do termo 'prece' nesse discurso nos faz lembrar da estreita aliança de Vargas com a Igreja e da importância da associação entre Igreja e nação nessa época, tanto em termos metafóricos quanto em relação às ações que foram empreendidas em parceria. A valorização da infância e especialmente da maternidade aparece como um ponto em comum de natureza estratégica. Borges (1991) fala dos projetos relativos à preservação da família (caracterizados na luta contra o divórcio e o aborto e contracepção, por exemplo) e à restauração da educação religiosa. Sobre a presença da Igreja no Estado e nas Constituições brasileiras com relação aos temas apontados, ver também Scampini (1978) e Cifuentes (1989).

D Quanto à política social em torno da criança na era Vargas, ver o trabalho de Fonseca (1993). É importante lembrar que desde a passagem do século a criança vinha começando a ser tratada como o 'futuro da nação' (Silva, 1997).

21 A Sociedade Brasileira de Ginecologia tem origem na Sociedade de Obstetrícia e Ginecologia do Brasil, que foi fundada em 16 de agosto de 1897, tendo entre os seus integrantes os principais nomes de destaque nacional na medicina dedicada às mulheres. A primeira diretoria era composta da seguinte forma: Feijó Junior (presidente), Rodrigues dos Santos (1 vice-presidente), Rodrigues Lima ( $2^{e}$ vice-presidente), Augusto 
Brandão ( $1^{\circledR}$ secretário), Carvalho de Azevedo ( $2^{\circledR}$ secretário), Vieira Souto (tesoureiro) e Rocha Freire (bibliotecário) (Brazil Medico, 304, 1897).

2 A Comissão Organizadora do Congresso era encabeçada pelo presidente da Sociedade Brasileira de Ginecologia, Arnaldo de Moraes. Entre seus membros estavam Nabuco de Gouvêa, Brandão Filho, Castro Araujo, Rodrigues Lima, Clovis Correa, Motta Maia, Jayme Poggi e S. Lemgruber, do Rio de Janeiro. Participavam também membros de outros estados, como São Paulo, Minas Gerais, Rio Grande do Sul e Bahia (Annaes Brasileiros de Gynecologia, 10:128, 1940).

23 Os outros temas eram: "Últimas aquisições da hormonologia ginecológica", "Endocrinopatias em obstetrícia", e "Diagnóstico e terapêutica do câncer cervical" (Annaes Brasileiros de Gynecologia, 10:128, 1940).

24 Smith-Rosenberg \& Rosenberg (1973) fazem referência ao uso do conceito de ginecologia social nas últimas décadas do século XIX nos Estados Unidos. O problema central dessa especialidade naquele contexto era a questão da queda da natalidade e a importância desse fenômeno para o futuro da nação e da raça.

๖ Pena (1981) destacou a conexão entre a formulação de leis trabalhistas, a desvalorização da mulher trabalhadora e o desenvolvimento de uma imagem da figura materna associada à nação durante a década de 1930. Barsted (1987), estudando o direito e as concepções do Estado sobre a família, afirma que na década de 1930 há uma articulação, inédita, da mensagem do Estado sobre a família com outras esferas como o trabalho, a previdência social, a criminalidade. Sobre a família no pensamento jurídico no século XIX, ver Almeida (1999).

2 Pena (1981) apresenta em detalhes a legislação e um panorama sobre o trabalho feminino na era Vargas.

z Nos Annaes Brasileiros de Gynecologia (v. 8, p.332, 1939) comenta-se o "Plano Nacional de Assistência à Maternidade", que passava a ser executado pela Divisão de Amparo à Maternidade e à Infância, coordenada por Olinto de Oliveira, do Ministério da Educação e Saúde.

23 Duarte (1999) mostra como as iniciativas do Estado Novo em torno da educação feminina centravam-se na preparação para a maternidade, as atividades domésticas e a formação de familias sadias e respeitáveis. 